\title{
A GENE SYNTHESIS REGIME FOR MALAYSIA TO EMULATE IN SECURING FUTURE BIOPRINTED VACCINES
}

\author{
MARINA ABDUL MAJID*
}

\begin{abstract}
The merger between synthetic biology and bioprinting will someday enable vaccines to be bioprinted utilising genetic material. Unregulated gene synthesis companies may unwittingly supply genetic material to a terrorist if there is no verification of purchasers ' personal identity and affiliation with a legitimate research organisation. This study has the objective of focusing on whether Malaysia regulates and conducts Deoxyribonucleic Acid (DNA) sequence screening among gene synthesis companies which are meant for bioprinting vaccines that can be misused for bioterrorism. This study is qualitative. Gene synthesis guidelines from the United States (US), the International Gene Synthesis Consortium (IGSC), the Nuclear Threat Initiative-World Economic Forum (NTI-WEF) Biosecurity Innovation and Risk Reduction report were referred as examples for changes in Malaysia's draft National Code of Conduct for Biosecurity [thereafter known as Code]. These soft law documents constitute the regime for gene synthesis and a form of transnational new governance. The findings indicate that in the absence of a specific binding regulation, Malaysia's draft Code must be amended to incorporate the need to screen customers, genetic sequences and address the cyberbiosecurity of biological life in digitalised form besides the physical biosecurity of laboratories which houses seedstocks from being stolen for malicious intent.
\end{abstract}

Keywords: Bioprinting; Draft national code of conduct for biosecurity; International gene synthesis consortium (IGSC); Cyberbiosecurity; Gene synthesis

\section{INTRODUCTION}

In 2012, J. Craig Venter announced that his team at the Institute for Genomic Research was assembling a biological teleporter, essentially a three-dimension (3D) printer that would be used to print vaccines (Hernandez 2012). The technique to print a vaccine using a 3D printer is known as bioprinting. Bioprinting is defined as "the printing of structures using viable cells, biomaterials and biological molecules" (Kacarevic et al. 2018, 1). A digital electronic file containing the Deoxyribonucleic Acid (DNA) code of a particular vaccine could be emailed from one part of the world to a receiving device and bioprinter in another geographical region. The bioprinter would need to be loaded with the necessary nucleotides, sugars and/or amino acids, which would be chemically linked up based on the instructions in the digital electronic file. This method to print a vaccine is currently being perfected and has the potential to save time in delivering vaccines during emergencies or epidemics in isolated regions, provided that a computer, bioprinter and the emulsion of nucleotides, sugars and amino acids are available at the receiving end.

Advancement in the area of synthetic biology has also spurred the advent of bioprinting. Synthetic biology is known as the merger between "science, technology and engineering to facilitate and accelerate the design, manufacture and/or modification of genetic materials in 
living organisms" (Raimbault, Cointet, and Joly 2016, 1). Synthetic biology aims to design artificial organisms. Trained professionals in advanced biology can replicate microorganisms solely by utilising chemicals and DNA sequences without a physical sample of a virus or bacteria obtained from a biological resource centre (BRC). Thus, Garrett $(2013,38)$ remarked, "the world of biosynthesis is hooking up with $3 \mathrm{D}$ printing, so scientists can now load nucleotides into a 3D "bioprinter" that generates genomes". At the same time, Koblentz (2020, 182) has warned that synthetic biology especially the ability to synthesise DNA from scratch to enable its creators to form customised genes and entire viral genomes risk being misused for nefarious purposes.

While the bioprinting of vaccines in the future should be welcomed, Galamas $(2015,9)$ cautioned that if bioprinters are made freely available to anyone, it may spur terrorists to acquire one to produce biological agents, since the sequencing of some pathogen DNA which are readily available from open sources can be misused to create a virulent pathogen. In turn, the terrorists might upload the emulsion of the virulent pathogen into a drone to disperse the hazardous material in a public place (Moore 2017). A bioterrorism event occurs to endanger lives and kill the public at large. Bioterrorism for this purpose is understood as "the intentional release of viruses, bacteria, or other germs that can sicken or kill people, livestock, or crops" (Centers for Disease Control and Prevention 2018). The United States (US) Weapons of Mass Destruction (WMD) Statute with reference to Title 18 U.S.C. Section 2332a defines bioterrorism as the threat (or conspiracy) to use a weapon of mass destruction, including any biological agent, toxin, or vector as defined in Title 18 U.S.C. Section 178 against a national of the US or within the US (US Department of Justice and Federal Bureau of Investigation $2011,10)$.

The developments related to bioprinting vaccines in the future raise regulatory challenges for any country. Tran $(2015,142)$ and, Pashkov and Harkusha $(2017,481-482)$ have emphasised the need for oversight and regulation concerning bioprinters, the emulsion of genetic materials used for bioprinting and the digital electronic file. Specifically in the area of gene synthesis and bioprinting, there have been calls to regulate these quickly burgeoning areas, be it by governments or through private initiatives (Colussi 2015, 20; Economic and Social Commission for Asia and the Pacific 2018, 9; Zhou et al. 2019, 18), as the legal system must be prepared for these new emerging technologies.

The regulation of gene synthesis began in the mid-2000s with the formation of the International Consortium for Polynucleotide Synthesis (ICPS) that called for a DNA synthesis order screening process and the formation of the International Association of Synthetic Biology (IASB), both in 2007 (Colussi 2015, 20; Diggans and Leproust 2019). With diverging views regarding how to proceed with regulating gene synthesis, the International Gene Synthesis Consortium (IGSC) was born in 2009, splitting from the IASB but similarly motivated to monitor customers ordering genes sequences, to check the sequences against the US Select Agent and Toxins list and to report any suspicious orders to the law enforcement agencies (Colussi 2015, 21; Perello 2018, 57; Zhou et al. 2019). These initiatives, until 2009, largely stemmed from private firms forming their own business associations to monitor gene synthesis technology in the absence of government legislation. It was not until 2010 that the first government regulation was formulated by the US Department of Health and Human Services (DHHS), called the Screening Framework Guidance for Providers of Synthetic DoubleStranded DNA, to monitor the gene synthesis industry (Colussi 2015, 21; Zhou et al. 2019). More recently, Trump et al. (2020,3) have briefly in scant passing mentioned about the Nuclear Threat Initiative-World Economic Forum (NTI-WEF) report to form a technical Consortium which would develop a common DNA sequence screening mechanism to be made available to gene synthesis companies worldwide. Most of these initiatives mentioned were in the form of non-binding documents called soft law, whether from government or private initiatives. 
Moreover, the initiatives to regulate gene synthesis originated from developed countries such as the US and those based in Europe. Germany on behalf of other European countries proposed the IASB Code of Conduct for Best Practices in Gene Synthesis in 2009 (Colussi 2015, 20).

While the US and countries in Europe have made progress in regulating gene synthesis, the same is not true of Asian countries. Yassif, Santhakumar, and Lightfoot $(2015,4)$ indicated in 2013 that the practice of regulating gene synthesis was slow and just beginning to spread to Asia. In 2017, Malaysia's representative from the Science and Technology Research Institute for Defence (STRIDE), which represented Malaysia at the Strategic Multilateral Biosecurity Dialogue involving Singapore, Malaysia, Indonesia and the US in Washington, D.C., was asked whether Malaysia had any regulatory measures in place to monitor gene synthesis companies or had procedures for screening orders and customers (Inglesby et al. 2017, 26). Unfortunately, the report of the said dialogue did not provide any information with regard to the Malaysian representative's response if the country had any regulatory measures to oversee gene synthesis companies. In 2018, the US and South Korea proposed to work together to encourage other countries to have their own nationwide screening standards to monitor gene synthesis technology and to establish a common code of conduct for suppliers of DNA, requiring them to perform screening and to report any suspicious orders (Woods et al. 2018, 30). Therefore, it is very timely to examine whether Malaysia has any regulation, be it in a binding or non-binding form that can be utilised to regulate the gene synthesis industry in this country, as this is a new grey area to be explored.

Thus, this study has the objective of focusing on whether Malaysia regulates and conducts DNA sequence screening among gene synthesis companies which are meant for bioprinting vaccines that can be misused for bioterrorism. Tran $(2015,172)$ as well as Pashkov and Harkusha $(2017,482)$ have called for the need to regulate the private sector, which supplies the genetic material for bioprinting, and to establish a supervisory administrative agency. The importance for Malaysia to regulate gene synthesis companies preferably through a binding initiative is to make it mandatory for these companies to record who orders the genetic sequences and to whom they supply the requested virus or bacteria to ensure that its purpose is legitimate such as the need to create a vaccine rather than being misused for bioterrorism. Should an incident of bioterrorism occurs, the relevant authorities would find it much easier to trace how a terrorist managed to acquire sequences for a virus or bacteria when gene synthesis companies records the personal details of their customers.

In accomplishing the above mission, it would be prudent to regard the regulatory framework of gene synthesis as an international regime based on all of the above initiatives combined together (Hyder 2015, 49). Furthermore, the merger between private and state initiatives to regulate gene synthesis worldwide has come to be known as a form of transnational new governance which covers the IGSC's Harmonised Screening Protocol (Committee on the Gene Drive 2016, 157). This being the case, this study will utilise regime theory as a theoretical framework which places all the private and state initiatives concerning gene synthesis in a model governance triangle in line with transnational new governance, which will later be elaborated in another section (Abbot and Snidal 2009).

\section{Gene Synthesis, Bioprinting a Vaccine and Its Bioterrorism Threat}

In March 2019, an alleged terrorist from the Islamic State of Iraq and Syria (ISIS), when interviewed by reporters, revealed his confidence in synthesising DNA (Speckhard and Shajkovci 2019, 3). The captured individual was quoted as saying, "I knew I could synthesise the biological and chemical weapons I researched on the web" (Speckhard and Shajkovci 2019, 3). Furthermore, this detained individual claimed, "I just needed the supplies and a wellequipped lab" (Speckhard and Shajkovci 2019, 3). With a background in computer science and 
having received a doctoral degree $(\mathrm{PhD})$ in India, this alleged terrorist, nicknamed Ahmed, seemed well versed in synthetic biology (Speckhard and Shajkovci 2019, 8). Ahmed is quoted as having said, "[I]n our lab in India [where he did his $\mathrm{PhD}$ ], I learned how to synthesise theoretically. We take the structure into a software and see how it works on this nerve, then we try it on animals" (Speckhard and Shajkovci 2019, 8). Obviously, Ahmed is no ordinary person, but rather one equipped with an advanced degree, recruited by ISIS for the purpose of developing biological and chemical weapons (Speckhard and Shajkovci 2019, 7). Notably, Ahmed is not relying on a physical sample of a virus or bacteria to develop a biological weapon but speaks of using one that would be synthesised. This is a far cry from the Japanese terrorist group Aum Shinrikyo, which in 1992 sent a medical group to the Democratic Republic of Congo on the pretext of providing aid for an Ebola outbreak but with the real intention of obtaining a physical sample of the virus (Maron 2014). In 2017, Gilles de Kerchove, the European Union's (EU's) counterterrorism coordinator, had warned about sympathisers to the ISIS cause with PhDs in synthetic biology (Moore 2017, 2). Ahmed's description of his ability to synthesise biological weapons is a true account of a terrorist knowledgeable of synthetic biology.

Not so long ago, in 2002, researchers from the State University of New York in Stony Brook were able to make a polio virus from scratch by combining short strands of DNA (Randerson 2006b, 2). In 2005, the Centers for Disease Control (CDC) in the US had utilised a published DNA sequence as a blueprint to reconstruct the Spanish flu virus (Gallegos and Peccoud 2017, 2). Currently, the DNA sequence of smallpox and other potentially dangerous pathogens such as poliovirus and the 1918 flu are easily obtainable on an online public database (Randerson 2006a, 1). Scientists have been able to reconstruct the viruses mentioned, thanks to the advancement in synthetic biology.

The COVID-19 epidemic which affected many countries worldwide with many reported deaths in the early part of 2020 have also led Ralph Baric, a scientist from the University of North Carolina to try to produce a synthetic copy of the virus (Regalado 2020, 2). Baric and his team are relying on the genetic sequence posted by Chinese scientists online to recreate an artificial version of COVID-19 by purchasing genetic sequences from gene synthesis companies and integrating them all together (Regalado 2020,2). Among some of the gene synthesis companies where custom DNA molecules can be obtained include Integrated DNA Technology, Twist Bioscience, and Atum (Regalado 2020, 2). Clearance had been obtained by the team of scientists from the University of North Carolina to reconstruct the virus from scratch for a noble cause in trying to find the right treatment by using various drugs that could react against the virus (Regalado 2020,4). Baric and his team are also registered scientists with the US CDC and were given permission to experiment with select agents (Regalado 2020, 6). As people worldwide are alarmed by the spread of COVID-19, gene synthesis companies which are able to synthesize genetic sequences to recreate the artificial COVID-19 virus will enable scientists to study the characteristics of the virus and to formulate a suitable vaccine.

If scientists are able to reconstruct the polio, Spanish flu and the COVID-19 virus through synthetic biology, this means that these viruses cannot truly be wiped out for good as modern biotechnology of present could enable their reconstruction. For this reason, prudence has been practiced among some large US gene synthesis companies which screen DNA sequences to ensure that legitimate individuals and authorised laboratories are the ones permitted to work with select agents for vaccine creation or other forms of treatment (Regalado $2020,5)$. The same practice though has been slow to be adopted universally among other countries which are unfamiliar with DNA sequence screening. The Global Health Security (GHS) index in 2019 indicated that "[n]o countries have legislation or regulations in place that require companies to screen DNA synthesis" (NTI and John Hopkins Bloomberg School of 
Public Health 2019, 12). With the exception of the US guideline and the private led initiative of the IGSC, it is really doubtful that most countries worldwide do practice DNA sequence screening. For the time being, it would seem that the ISIS believers who are keen to spread the COVID-19 virus are relying on rudimentary means to spread this scourge. This is evident from the believer's writings in the Voice of India magazine which states:

[e]very brother and sister, even children, can contribute to Allah's cause by becoming the carriers of this disease and striking the colonies of the disbelievers, whenever they find them (Mishra 2020, 2).

The above statement shows that ISIS believers intend to spread the COVID-19 from person to person without any sophisticated synthetic biology manipulation. However, it cannot be discounted that ISIS may resort to more sophisticated means of synthetic biology in manipulating select agents as evident by the existence of Ahmed, a $\mathrm{PhD}$ graduate from India discussed previously. For this reason, countries worldwide should heed the warning from the United Nations Secretary General, Antonio Gutterres who stated:

[t]he international community must remain vigilant. Scientific advances are reducing technical barriers which earlier limited the potential of biological weapons (Aiyappa 2020, 1).

The scientific advancement as referred to could cover developments in synthetic biology easing the way to develop pathogens of concern. The danger lies if terrorists may resort to synthetic biology to create a dangerous pathogen although it might not be that easy since tacit knowledge and years of experience as a scientists are also integral to creating such a successful venture. Countries should therefore strive to educate themselves on how best they can adopt DNA sequence screening measures as a precautionary measure to prevent terrorists from acquiring the necessary for bioterrorism.

As for Craig Venters' digitalised life sending unit that can print a vaccine, it functions by sequencing a genome from a sample and forms a digital genome sequence. The sequence generated is channelled to a digital biological converter that creates the vaccine. The bioprinter which prints the vaccine must be ready, equipped with the relevant emulsion of genetic material consisting of nucleotides, amino acids and sugars. This can be obtained from a commercial or open source gene synthesis facility. The ability to bioprint a vaccine is currently being finetuned. Venter and his team have already utilised this bioprinting technology during the H7N9 virus outbreak in China (Mary Ann Liebert Inc. 2014), when the virus sequence was downloaded from the internet and synthesised at the behest of the CDC and Novartis.

The digital file containing information to create a vaccine can be sent in a secure email to any part of the world. The danger lies in a terrorist succeeding in hacking the digital file and changing a few codes to create a deadlier and more virulent virus rather than a vaccine. Concerns of this nature have raised the alarm of cyberbiosecurity. Cyberbiosecurity is defined as "understanding the vulnerabilities to unwanted surveillance, intrusions, and malicious and harmful activities which can occur within or at the interface of coming led life and medical sciences, cyber, cyber-physical [...] and developing and instituting measures to prevent, protect against, mitigate, investigate and attribute such threats as it pertains to security, competitiveness and resilience" (Murch et al. 2018, 1). Ahmed, the alleged terrorist mentioned earlier, was able to hack into many scientific databases to obtain relevant journals that would enable him and his ISIS colleagues to create biological weapons by entering the dark web and entering a Russian website that cracked the journals code (Speckhard and Shajkovci 2019, 9). Ahmed also resorted to utilising Russian search engines which is secured and a browser to hide his search (Speckhard and Shajkovci 2019). Hence, it cannot be assumed that a terrorist is incapable of hacking a digital file containing a genetic sequence of an organism meant for a vaccine, as the case of Ahmed has proven otherwise. 
By the same token, a terrorist can produce a virus or bacteria by relying on DNA building blocks such as Biobricks. Biobricks provide DNA constructs from different functioning parts that are put together to create an existing or totally new form of organism (Strategic Foresight Initiative 2013, 18). Biobricks can be purchased and downloaded with a specific functionality. As Bajema $(2018,8)$ puts it, "researchers can now search these online catalogues for sequences of interest and analyse the data and have them synthesised to work with them in a lab environment". Subsequently, the organism designed using Biobricks, be it a virus or bacteria, is sent to a bioprinter that will print the new life form from genetic materials. Observably, the realm of biotechnology has been transformed from one requiring physical manipulation of a scientist's skill to manipulate an organism, its development and production to one of bioinformatics involving sequencing, online databases containing genetic sequences and its information all enabled with voluminous big data. Big data itself has been defined by the European Commission as "large amounts of data produced very quickly by a high number of diverse sources [such as those] created by people or generated by machines [which] gather[s] climate information, satellite imagery, digital pictures and videos, purchase transaction records, [global positioning systems (GPS)] signals, [and other sources]" (European Commission 2019, 1). Big data encompass many sectors such as healthcare, transport, energy and many more. Big data has contributed to the easier genetic sequencing of genomes from various bacteria, viruses and toxins as scientists using various methods, software and mathematical models have been able to organize the voluminous data being generated, to make sense and interpret the data.

A terrorist who created an existing and known or totally new organism based on the functioning parts of Biobricks can email the digital file to his colleague in another region to launch a bioterrorism attack. This is because digital information, while being stored in physical devices and moving through the physical system of networks, cannot be contained physically as it knows no state boundaries or jurisdiction. The digital file itself contains embedded expertise whereby, before its distribution, scientists and engineers can test the workability of the file to ensure it functions properly and is devoid of errors. A terrorist utilising a digital file to build an organism need not be a software engineer but must be trained to use a computer with design software that designs the organism he wants. This is known as de-skilling, a "process of reducing the level of technical expertise or complexity of use required for successful employment" (Snow 2015, 26). According to Bajema $(2018,10)$, besides the digital files, the 3D printers, bioprinters and DNA sequencers lead to de-skilling regarding the technical expertise needed to create organisms aided by this Information Communication Technology (ICT) equipment that is currently being projected. This ICT equipment, once further finetuned, could reach a very advanced stage, to the point where "some areas may approach push button technology in the near future" (Bajema 2018, 10). Dunlap and Pauwels $(2017,2)$ characterise the biological lab of the future as being more information-intelligent with "its machines requiring less tacit knowledge for use and analysis". The digital biological converter (DBC) that Venter has created has erased the step in synthetic biology of linking oligonucleotides together to form larger genes, as a DNA sequence can simply be entered into the equipment and be printed instantaneously (Dunlap and Pauwels 2017, 3). While it is true that the synthesis of DNA fragments can easily be obtained from commercial suppliers, the need for tacit knowledge among researchers to assemble the DNA fragments and insert the product into a cell as a functional genome can prove to be challenging, requiring the technical expertise of trial and error based on intuitive skills acquired through years of experience in synthetic biology. However, the DBC could set a precedent for other scientists and engineers who are affiliated with ISIS to lend their skills in writing a digital file to make a virus or bacteria virulent and contagious to sell it on the dark web to earn money. Terrorists frequent the dark web, as it offers anonymity and presents difficulties for law enforcement in tracking the activities of terrorists. 
The regulatory issues which arise from the bioprinting of vaccines would include the need to restrict the sale of bioprinters to purposes exclusively related to medical and educational research (Foster 2016, 35). Another issue is the need to make gene synthesis companies more responsible for knowing who is ordering the DNA sequence and for assessing whether the DNA sequence requested belongs to a select agent list of pathogens of concern. The next section will focus on the US guidance document to monitor gene synthesis components, those who are involved in gene sequencing and those who supply the genetic material, as a model of best practice that can be emulated by Malaysia.

\section{REGIME THEORY AS THE THEORETICAL FRAMEWORK IN EXPLAINING THE GOVERNANCE OF GENE SYNTHESIS}

Regime theory traces its roots to the liberal tradition. For the purpose of this study, a regime is "the full set of actors, institutions, norms and rules" constituting a particular regulatory arrangement (Eberlein and Grande 2005, 91). Scholars have traditionally considered states to be the sole creators of regimes (Cutler, Haufler and Porter 1999, 13; Tusikov 2017, 324). The focus on the state as the creator of rules and the enforcers of compliance has restricted the notion of a regime to that of formalised rules like treaties, conventions and international agreements and, at the national level, the formulation of statutes by states. Regime formation occurs when there is a convergence of interest on an issue that draws various actors together, be they states or non-state actors. Once a regime is formed, its members are expected to adhere to an established standard of behaviour and to have a sense of obligation with regard to their pledges.

Critics of regime theory suggest that other non-state actors such as private firms, multinational corporations (MNCs) and non-governmental organisations (NGOs) are equally capable of forming a regime (Cutler, Haufler and Porter 1999, 14; Bradford 2007; Cutler 2004, 27). This has led to the term "private international regimes", defined as "instances of global governance relations or of private international authority" (Cutler 2004, 23). An alternative meaning has been proposed by Haufler $(1993,100)$, namely that a private regime is "one in which co-operation among private actors is institutionalised, and in which states do not participate in formulating the principles, norms, rulers or procedures which govern the regime members' behaviour". Private regimes may come into being when like-minded firms in a particular industry or issue area decide to negotiate among themselves to form a business association, which produces soft law non-binding documents such as codes of conduct and guidelines for the business transactions of its members. Therefore, firms and MNCs, nationally or internationally, would voluntarily abide by these soft law documents. As the composition of these business associations consists of domestic and overseas firms, private regimes are very much transnational in nature (Tusikov 2017, 341). Transnational denotes "an organisation working beyond state boundaries and acting independently from traditional state authorities" (Thiel and Maslanik 2017, 1). In this sense, private regimes are self-regulatory (Cutler 2004, 23; Tusikov 2017, 341). Business associations or consortiums which normally come together are regarded as self-generated or spontaneous regimes arising from a convergence of expectations and not requiring a conscious effort among members to facilitate regime formation through strenuous negotiations. Schoten and Hospes $(2018,1)$ have highlighted the prevalence of private actors being the trend setter for rule making since the 1990s which concerns environmental sustainability issues such as forestry, biofuels, aquaculture, sustainable agriculture commodities and responsible mining. Beyond these issues, there is a need to investigate if private actors' rulemaking have started to venture into new areas such as gene synthesis to set an example for states to emulate. 
Private regimes are formed for many reasons. At times, non-state actors decide to form their own regime to cover existing gaps in regulation when law has not been drafted in a particular grey area (Bas 2003, 34; Tusikov 2017, 343). At other times, states cannot cope with drafting laws which reflect rapid technological changes or address newly emerged risks, requiring private regimes with the necessary technical expertise to fill in this gap (Bas 2003, 34; Cutler 2004, 31; Tusikov 2017, 347). Moreover, the corporate sector may resort to drafting soft law documents when there is a need to harmonise competing or uneven rules, to pre-empt government regulation or to moderate existing rules (Tusikov 2017, 343).

The incentives to comply with the rules created by a private regime can be based on several factors. Unlike states, which have the power to enforce rules and punish wrong doers through formal laws and trials, private firms do not have such enforcement capacities. Instead, peer pressure is used to enforce rules or to threaten to withhold business deals should a party fail to comply with the norm (Tusikov 2017, 345). Fear of a business scandal and damage to a business firm's reputation can also induce compliance with non-binding documents formulated by private regimes (Tusikov 2017, 348).

The role of the state with regard to a private regime is very much restricted. States merely direct, oversee and spur the drafting of private regulation (Tusikov 2017, 34). States can also provide incentives to private firms to formulate and enforce rules. At times, states may also endorse private regulation or incorporate parts of it into formal law (Tusikov 2017, 349). Once a private rule is adopted by a state and incorporated into law, adherence to it becomes compulsory (Bas 2003, 34). Schouten and Hospes $(2018,2)$ have regarded a state's adoption of a private regulation into formal law as a form of substitution. Akpoviri, Zainol and Baharum $(2020,70)$ are of the view that self-governance among the private sector and government regulation in the area of synthetic biology is crucial as a government can provide effective enforcement mechanisms to strengthen public confidence that the private sector may not be able to do.

There are benefits in resorting to non-binding initiatives within private regimes. These soft law documents are much easier to amend when there is a need for expansion or contraction based on the need of stakeholders. In terms of private regimes' effectiveness, there are complications regarding evaluation. Unless private regimes produce public reports of their accomplishments, including their effectiveness and progress in introducing privation regulation, their work remains undocumented (Tusikov 2017, 349).

As for the introduction of private regimes, there is a tendency for initiation to come from developed rather than developing countries. At times, developing countries are unaware of a soft law initiative from a private regime originating from a developed country until the soft law initiative is publicised on the internet or media. Private firms in developing countries may incorporate a soft law initiative from abroad as their best practice, following rather than initiating (Tusikov 2017, 349).

Private regimes can jointly produce regulatory rules together with a state government to form a private-public partnership which is a hybrid system (Veiga and Zacareli 2017, 50). Abbot and Snidal $(2009,509)$ call the simultaneous creation of regulations between the state, private sector and NGOs "Transnational New Governance". The formulation of guidelines and codes of conducts by a private regime can complement the state-based regulatory structure. In this new form of governance, rulemaking is no longer top-down but decentralised, composed of both public and the private regulators. The role of the state is limited to encouraging and supervising self-regulation, sponsoring voluntary management systems and relying on private technical expertise with the result of soft law documents being produced (Abbot and Snidal 2009, 509). Abbot and Snidal $(2009,510)$ have asserted that this new form of governance should be promoted "to ameliorate the persistent regulatory inadequacies of international 'Old Governance"”. To depict this new form of governance, Abbot and Snidal $(2009,511)$ have 
created a model Governance Triangle to show the diversity of Regulatory Standard-Setting (RSS) scheme incorporating three main actors who formulate regulation, namely the state (Zone 1), private firms and MNCs (Zone 2) and NGOs (Zone 3), as depicted in Figure 1 below. The category of NGOs covers advocacy groups, labour unions, non-profit organisations, student groups and other civil society organisations (Abbot and Snidal, 2009, 516). The firms' category in Zone 2 includes small and medium enterprises (SMEs) nationally or internationally and MNCs. Zone 1 in the state category includes both developed and developing countries' formal and informal regulation, such as guidelines, codes of conduct, or a statute formulated by a state or its governmental agencies (Abbot and Snidal 2009, 516).

In this study, four documents pertaining to gene synthesis are referred to: the United States Screening Framework Guidance for Synthetic Double-Stranded Deoxyribonucleic (DNA) providers, a national state initiative placed in Zone 1 of the governance triangle in Figure 1; Malaysia's draft National Code of Conduct for Biosecurity, also placed in zone 1 as a state initiative; and the International Gene Synthesis Consortium (IGSC) Harmonised Screening Protocol Version 2.0 (V 2.0), which brings together private firms and MNCs as a business association to formulate a standard to guide the gene synthesis industry, a firm initiative placed in zone 2 while the joint report between the NTI-WEF on Biosecurity Innovation and Risk Reduction: A Global Framework for Accessible, Safe and Secure DNA Synthesis is placed between zone 2 and 3 as it is a joint initiative between an NGO and business forum. Regarding the categorisation of the IGSC's Harmonized Screening Protocol V 2.0, the Committee on the Gene Drive Research in Non-Human Organisms: Recommendations for Responsible Conduct $(2016,167)$ has placed this initiative as a private industry standard under the example of transactional governance tools in science. The IGSC's Harmonized Screening Protocol V 2.0, the US Screening Framework Guidance for Synthetic Double-Stranded DNA Providers, and that of the NTI-WEF initiative are used as models for Malaysia's own Draft National Code of Conduct for Biosecurity with regard to best practices to emulate. This study asserts that the four documents placed in the governance triangle, as in Figure 1, would constitute an international regime of self-interested gene synthesis actors consisting of national governments, a business consortium and NGO who are all interested in regulating the industry through soft law documents. This is in view of the potential for terrorists to misuse gene synthesis for bioterrorism, a biosecurity threat. Hyder $(2015,49)$, for instance, refers to the protocols developed by the IGSC and the IASB as a wide-reaching international regime (consistent with this study's usage of regime theory) to depict the worldwide regulation of gene synthesis, seen in Figure 1, which forms the theoretical framework for this study. Subsequent sections will elaborate in further detail the contents of each of these soft law documents that monitor gene synthesis. 


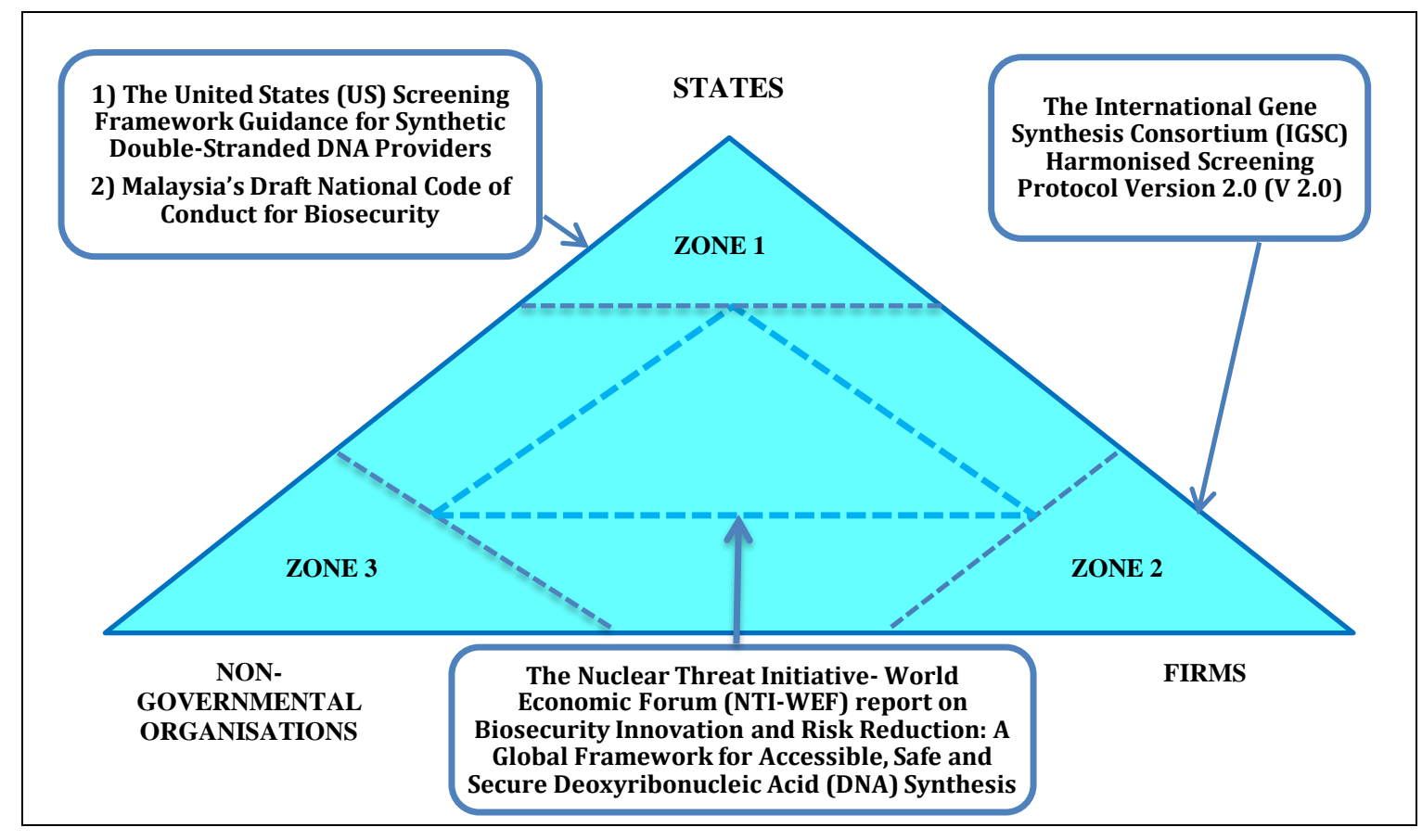

Figure 1: The Regime of Gene Synthesis forming a Transnational New Governance Framework, adapted from Abbot and Snidal (2009)

\section{METHODOLOGY}

This study is qualitative as there is a high reliance on soft law to be examined, namely the IGSC's Harmonised Screening Protocol Version 2.0 (V.2) of 2017, the US Screening Framework Guidance for Providers of Synthetic Double-Stranded DNA, the NTI-WEF Biosecurity Innovation and Risk Reduction: A Global Framework for Accessible, Safe and Secure DNA Synthesis Report of 2020, and Malaysia's Draft National Code of Conduct for Biosecurity in the Framework of the Biological Weapons Convention (thereafter known as Code). These documents will be closely scrutinised to identify best practices in gene and customer screening as well as any reporting procedures to authorities, should there be any request for a gene sequence of concern that may be utilised for bioterrorism. Essentially, this study will identify and suggest the means by which Malaysia's draft National Code of Conduct for Biosecurity can be improved by learning from the best practices of private initiatives for gene synthesis and of US regulation.

As this study is multidisciplinary, involving science, law and security studies, a sociolegal approach is adopted. Socio-legal research is one which permits "wide-ranging and varied area of research activity" and a diversity of methods and perspectives to be used - a description provided by the United Kingdom's Economic and Social Research Council (Cowney and Bradney 2013, 35). A socio-legal approach is also utilised in this study because the social science method of analysis is applied. An analysis and interpretation of soft law documents is performed.

Besides these, this study also relied on secondary resources such as journals, book chapters, books, working papers, conference papers, reports, newspapers, magazines, and governmental and international organisation websites to obtain information on the overview of gene synthesis and bioprinting worldwide and how these technologies could be misused for bioterrorism. Readings from these secondary resources were grouped as themes through a content analysis and arranged into relevant sections in this study. 


\title{
RESULTS AND DISCUSSION
}

\author{
The United States Screening Framework Guidance for Synthetic Double-Stranded \\ Deoxyribonucleic (DNA) Providers
}

In 2006, a reporter from the Guardian newspaper in the United Kingdom (UK) ignited security concerns when he managed to order a short sequence of the smallpox DNA from VH Bio Limited, which was unaware it was supplying part of a smallpox genome (Randerson 2006a, 1). It was also then reported in 2006 by the New Scientist magazine that out of 12 gene synthesis companies surveyed in North America and Europe, merely five reputedly screened their orders for sequences of concern that could be utilised for making a biological weapon (Randerson 2006a, 1). Subsequently, this led to a recommendation for DNA synthesis companies to use the ICPS approved software to verify synthesis orders against a set of select agents or sequences (Bügl et al. 2007, 629). Synthetic biology companies were also urged to work closely with government authorities, alerting them of any suspicious DNA sequence being ordered and identifying the individual or organisation placing the order (Bügl et al. 2007, 629).

In 2010, the DHHS in the US drafted the Screening Framework Guidance for Synthetic Double-Stranded DNA Providers, which was open to the public for comments. Among one of the requirements in this US guidance was the need to screen customers and their backgrounds, identifying them as principle users or a known organisation, respectively (DHHS 2010, 2-3). Customers are required to provide additional information about themselves in case their sequence orders raise red flags concerning select agents and toxins of concern (DHHS 2010, 2). Select agents are "biological agents and toxins that have been determined to have the potential to pose a severe threat to public health and safety, to animal and plant health, or to animal or plant products" (Centers for Disease Control and Prevention 2020, 1). Among some examples of select agents include coxiella burnetii (Q fever), lassa mammarenavirus (lassa fever virus), rickettsia prowazekii (typhus), henipavirus (nipah virus), marburg virus, Eastern Equine Encephalitis virus (sleeping sickness) and other forms of select agents. In cases whereby customers were unaffiliated with a known organisation, they must provide references who can verify their personal details and the legitimacy of their order (DHHS 2010, 3). The guidance document also eliminates the 200 base pair limit for screening double-stranded DNA for synthesis and mandates that all DNA orders be screened (DHHS 2010, 3). Additionally, the screening of sequences must be made against the US Select Agents and Toxins list, while for international orders there is a requirement to also screen against the US Commercial Control List (CCL) (DHHS 2010, 4). The US guidance does not provide the need to screen against nonselect agent homologs that are closely related to a select agent, because the knowledge of virulence and pathogenicity as of 2010 was limited, and it was not possible to develop clear criteria for providers to be used as a reference "to robustly, comprehensively, and consistently identify non-select agent and toxin or non-CCL" (DHHS 2010, 4). The guidance also recommended the usage of software for screening DNA sequences of concern (DHHS 2010, 6). Finally, the Guidance would apply to all providers of synthetic double-stranded DNA and not merely to commercial providers (DHHS 2010, 7).

The International Gene Synthesis Consortium (IGSC) Harmonised Screening Protocol V 2.0

The IGSC was first formed in 2009 and in 2015 became a non-profit corporation (IGSC 2017, 1). The IGSC is an industry initiative to conduct gene sequence and customer screening of orders to promote biosecurity voluntarily. The IGSC has twice revised its Protocol to assist 
synthetic biology companies to screen DNA sequences of concern and to conduct customer screening.

Paragraph 2.2 of the IGSC Protocol in 2017 recommends that its members screen the complete DNA sequence from a common Regulated Pathogen Database (RPD) which includes all pathogens and toxins from the US Select Agents and Toxins List, the US CCL, the EU list of dual-use items, the Australia Group List and other national lists of regulated pathogens (IGSC 2017, 1). Dual use items include "a wide range of goods that are designed for commercial applications, but can have military applications or potentially be used as precursors or components of weapons of mass destruction" (Singapore Customs 2019, 1). Dual use items may include select agents such as yersinia pestis (plague), bacillus anthracis (anthrax), botulinum toxin (botox), francisella tularensis (tularenisis), burkholderia pseudomallei (melioidosis) and other agents and toxins which can be used for the good of mankind to create vaccines or it could be modified to become a virulent pathogen used for nefarious purposes.

As for its customer screening, paragraph 3.1 of the IGSC Protocol asserts that shipping will not be made to any Post Office (PO) boxes but only to a legitimate shipping address. Personal details such as an affiliated institution, country, phone number and email address must be provided. Paragraph 3.3 of the IGSC Protocol states it will only supply genes from regulated pathogens to bona fide end users, which include government laboratories, universities, nonprofit research institutions and industrial laboratories engaged in valid research (IGSC 2017, 2). Paragraph 2.4 of the IGSC Protocol indicates should a potential pathogen or toxin sequence be detected, a human expert will review the application using IGSC screening criteria to either accept, accept with additional information from the customer or downright reject an application (IGSC 2017, 2).

With regard to record keeping, paragraph 4.1 of the IGSC Protocol stipulates that an order be maintained in its database for eight years to include the synthetic DNA sequence, the vector, the recipients' identity and shipping address (IGSC 2017, 2).

In relation to order refusal and reporting, paragraph 5.1 of the IGSC Protocol asserts that members have a right to refuse a suspicious order of concern and to notify other IGSC members (IGSC 2017, 3). Establishing contacts with national law enforcement and informing authorities to report a suspicious order and prevent the misuse of synthetic genes are also stipulated in paragraph 5.2 of the Protocol (IGSC 2017, 3). Paragraph 6.1 of the IGSC Protocol stresses that members must also comply with the rules and regulations of a country. This might include rules concerning the synthesis, possession, transport, export control law and import of any suspicious pathogens and toxins of concern (IGSC 2017, 3). Most importantly, paragraph 6.2 of the Protocol asserts that IGSC members must never synthesise the gene sequence unique to the variola virus DNA (IGSC 2017, p. 3). Besides the above, the IGSC members are required to constantly update the RPD and use the most effective algorithms for screening as contained in paragraph 7.2 of the Protocol (IGSC 2017, 3).

With regard to Malaysian organisations and universities being aware of this Protocol, the Malaysian Biotechnology Information Centre (MABIC) and a representative from University Technology Malaysia (UTM) had attended an event known as the Applications for and Security Aspects of Synthetic Biology in 2013 in Hong Kong (1540 Committee 2013). This event had highlighted that "gene foundries (companies that synthetically manufacture genes to order commercially) are appearing in the People's Republic of China and their share of the world trade in synthetic genes has grown considerably and continues to do so while other emerging centers are in the Far East, such as India and Malaysia" (1540 Committee 2013, 2). At this event, the Malaysian representatives were exposed to the first version of the IGSC's Protocol drafted in 2010. The event had the intention of spreading and "to globalise adherence to the Codes [IGSC Protocol and the IASB's Code of Conduct for Best Practices in Gene Synthesis of 2009]" (1540 Committee 2013, 2). Despite the attempt to spread the adherence to 
the said Codes, in Malaysia there has been silence and not much publicity with regard to the IGSC's Protocol. This does not auger well for Malaysia in view of the growing gene synthesis companies in the country. Awareness of the IGSC Protocol in Malaysia must be raised by the relevant authority to safeguard against the creation of pathogens by terrorists with the malicious intent of bioterrorism.

\section{THE NUCLEAR THREAT INITIATIVE-WORLD ECONOMIC FORUM (NTI-WEF) PROPOSAL TO REQUIRE SCREENING THE DEOXYRIBONUCLEIC ACID (DNA) SEQUENCE AS A NORM}

A recent effort by the NTI-WEF in 2019 had led to an international expert Working Group on Preventing Illicit Gene Synthesis from being used for nefarious purposes (NTI-WEF 2020).

A consortium which comprises of two or more companies, or governments that cooperate among one another to achieve a common objective has been proposed in 2020 to form a common DNA sequence screening mechanism (NTI-WEF 2020). This DNA sequence screening mechanism would be low cost and easy to use by DNA providers and for those providing benchtop DNA synthesis machines (NTI-WEF 2020). While the IGSC as previously discussed had already developed a harmonised screening protocol to prevent double stranded DNA encoding pathogenic processes or toxins from being misused for malicious intentions, this has been limited to companies aligned with the IGSC. There are still other gene synthesis companies in existence which are non-parties to the IGSC and may not subscribe to the best practices of DNA screening put forth by the IGSC. More worrying are the gene synthesis companies in existence among developing countries that are unaware about the importance of screening dangerous DNA sequences that may be misused for bioterrorism. In this spirit, the NTI-WEF have proposed to make synthetic DNA screening a global norm among countries, researchers, institutions as well as providers of DNA and suppliers of benchtop DNA synthesis machines (NTI-WEF 2020, 11).

In realising a common DNA sequence screening mechanism, the first step is to ensure there is an international and expert consensus with regard to DNA sequences that would cause harm when misused by holding a few meetings among countries, experts and business representatives. Only when a consensus is reached will there be an opportunity to create a common DNA sequence screening mechanism with an internationally recognised set of sequences of pathogens as well as toxin DNA and algorithms to screen the DNA sequences (NTI-WEF 2020, 8). Security of the DNA sequence screening mechanism is of grave concern as cyberbiosecurity precautionary measures should be taken to ensure that this mechanism is housed securely, to make its availability in encrypted form, the usage of cloud based systems, and limiting the access of this mechanism to legitimate users (NTI-WEF 2020, 9). A consideration should also be made in prohibiting sequences which can cause harm from being produced by the benchtop DNA synthesis machines by incorporating a build in version of the screening mechanism so that it will automatically disable the synthesis of an unauthorised pathogen or toxin DNA (NTI-WEF 2020, 9). Should a DNA sequence that can cause harm is being ordered, consecutive action requires for a thorough check of the customer's background if he/she is a legitimate researcher or user within a university or research institution within a country. If there are doubts about a customer's background and his/her purpose of ordering a synthesised pathogen or toxin DNA, the security enforcement authorities should be alerted to conduct further checks. It is paramount to always check a DNA sequence first in case it is one which causes harm before ever synthesising the sequence. 
Other functions of the proposed Consortium would include the following actions. Semiannual meetings would be held to include new scientific findings, and incorporate new technological and algorithmic advances among the common screening mechanisms. The Consortium is also anticipated to act as a repository for resources and information concerning a common set of sequences and screening platform which would encompass regulations and guidance pertaining to synthetic DNA, customer screening and best practices related to DNA sequence screening (NTI-WEF 2020, 9). By 2021, it is anticipated that the common DNA screening mechanism be supplied to all DNA providers as well as the developers and providers of benchtop synthesis machines (NTI-WEF 2020, 7).

With regard to an oversight mechanism being able to monitor the DNA screening mechanism being practiced worldwide, it has been proposed that an existing international entity or new organisation be created to fulfil the mandate (NTI-WEF 2020, 11). The Consortium is recommended to work with states, international organisations, industry groups, universities and other parties to ensure that the screening of DNA sequences becomes a norm practiced worldwide. The role of national governments is paramount in cultivating the practice to screen DNA sequences by making this requirement mandatory through legislation or regulations and the issuing of certification for DNA providers and those of benchtop DNA synthesis machines (NTI-WEF 2020, 11). A national agency contact point will have to be appointed to receive queries and complaints when there are reports of illegitimate users ordering DNA sequences which can cause harm that might be meant for bioterrorism, biowarfare or biocrime (NTI-WEF $2020,11)$. A country's biosecurity law and its regulations could be amended to incorporate making DNA screening mandatory too (NTI-WEF 2020, 11). Research funders could also make DNA screening a mandatory requirement as part of the criteria for awarding a research grant for researchers to obtain DNA sequences only from legitimate DNA synthesis companies that subscribes to the said practice (NTI-WEF 2020, 12). NGOs could also issue ratings, accreditation, awards and seals of approval to researchers among universities and research institutions worldwide that practice synthetic DNA screening (NTI-WEF 2020, 12).

As pertains to the role of international organisations, a proactive stance in promoting the norm to screen DNA sequences among countries so that this practice will be adopted worldwide is imperative. Among some of the international organisations related to biosecurity and biosafety which have been identified to play a vital role in enforcing the said practice include the United Nations (UN), the World Health Organization (WHO), the World Organisation for Animal Health (OIE), the United Nations Office for Disarmament Affairs (UNODA), the Biological Weapons Convention (BWC) Implementation Support Unit, and the United Nations Security Council Resolution 1540 Committee (NTI-WEF 2020, 12). Other related international bodies that have been voluntary formed by states that could play a promotional role would also include the Australia Group and the Global Partnership against the Spread of Weapons and Materials of Mass Destruction.

As the evolution of screening DNA sequences have started to gravitate from private regulation and limited state practice towards a proposal to one managed by an international consortium or parked under the mandate of an existing international organisation, it is very timely for various states to take stock of these recent developments. States must now act and amend existing or propose new law or regulations to accommodate the screening of DNA sequences to match the current international developmental pace occurring globally or will be left behind.

\section{Malaysia's Draft National Code of Conduct for Biosecurity}

In June 2015, a Workshop on the Development of a National Code of Conduct for Biosecurity in the Framework of the Biological Weapons Convention (BWC) convened in Malacca, 
Malaysia (Science and Technology Research Institute for Defence (STRIDE) and Cooperative Biological Engagement Programme (CBEP) 2015). At this workshop, STRIDE had presented the draft Malaysian National Code of Conduct for Biosecurity in the Framework of the BWC. This draft Code though needs to be updated with recent developments in biotechnology and to be in line with the calls from the NTI-WEF for countries to form national legislation or regulation that would make DNA sequence screening compulsory since this aspect is unregulated currently among most countries (NTI and John Hopkins Bloomberg School of Public Health 2019).

Two of the issues addressed in the draft Code include biorisk assessment (BRA) and biorisk management (BRM) (STRIDE and CBEP 2015). Risk assessment requires "the screening of potential misuse of the biological materials which can be intentionally abused" (STRIDE and CBEP 2015, 36). Notably, Malaysia's draft Code is intended for organisations, institutes and companies which deal with biological agents with potential risk (STRIDE and CBEP 2015, 34). The Code also emphasises the need to raise awareness with regard to third parties' responsibilities, which may include gene synthesis companies (STRIDE and CBEP 2015, 37).

The problem with the Malaysian draft Code of Conduct for Biosecurity is that it fails to acknowledge the recent developments in synthetic biology and bioprinting, which may be an alternative way for terrorists to develop biological weapons. While the draft Code rightly addresses the accessibility and physical security of laboratories where biological agents may be stored and the necessity for scientists "to use good, safe and secure laboratories procedures" (STRIDE and CBEP 2015, 38), it should also acknowledge technological developments of synthetic biology and bioprinting whereby chemical synthesis without the seedstock of a biological agent stored in a laboratory can lead to the development of a biological weapon. A Malaysian representative from STRIDE in 2017 once noted that information on altering an organisms' DNA has become easily available with rapid developments in biotechnology and bioengineering (Firdaws 2017, 2). This could imply a reference to synthetic biology which might ease the creation of biological agents for terrorists. Unfortunately, the draft Code is outdated in this aspect and the final version of this Code should include gene synthesis precautions regarding producing select agents and toxins of concern and bioprinting a virulent pathogen. Through international participation at the Symposium on Promoting Institutional Oversight Mechanisms to Address Biosecurity Threats from Emerging Technologies, held from 10-12 September 2019 in Putrajaya, Malaysia, the Malaysian authorities were informed of the research biorisk of synthetic biology and gene editing (Academy of Sciences Malaysia 2019). Hopefully, awareness will spur a specific regulation to monitor gene synthesis companies in Malaysia.

Malaysia's draft Code is also deficient because it fails to acknowledge who will control access to the genetic material available from commercial or opensource gene synthesis facilities in Malaysia and abroad. There is a need to explicitly mention the role of gene synthesis companies and to control the supply of genetic materials. There is also a need to identify the relevant authority that would monitor these companies and their recipients. If the Code is currently not being able to address best practices regarding gene synthesis companies, it is suggested that STRIDE in Malaysia draft a separate guidance for synthetic double-stranded DNA providers following the IGSC Harmonised Screening Protocol Version 2.0, as discussed earlier.

In addition, the Malaysian draft Code of Conduct for Biosecurity fails to maintain currency with the technological progress in bioprinting by not monitoring who should have access to bioprinters. Bioprinters are directly available commercially and their market price is expected to decrease. In line with this development, it is suggested that the Medical Development Authority (MDA) in Malaysia might restrict access to bioprinters in the future 
by limiting them to legitimate medical practitioners and scientists of recognised universities and organisations. Bioprinters cannot be made available to the public at large, given their potential for misuse and the fear that they might fall into terrorist hands.

There are also some positive aspects of Malaysia's draft Code that could apply to gene synthesis companies in this country. The aspect of the Code concerned with raising awareness, education and information could be utilised to create awareness about the dual-use dilemma of genetic materials produced by gene synthesis companies for bioprinting. Genetic material may be used for the creation of a vaccine for the good of humankind. On the other hand, the genetic material produced may be misused to create a biological weapon; these are the potentials of bioprinting that create a dual-use dilemma. The draft Code also stresses the need to "disseminate information about and teach national and international laws and regulations, as well as policies and principles aimed at preventing the misuse of biological research" (STRIDE and CBEP 2015, 38). In light of this development, it is very timely to create awareness and spread good practices of gene synthesising among gene synthesis companies, universities and research institutions in Malaysia by emulating the US Screening Framework Guidance for Synthetic Double-Stranded DNA Providers and the IGSC Harmonised Screening Protocol Version 2.0. There is currently a lack of publicity and knowledge of these two vital documents among the relevant stakeholders in Malaysia.

Other highlighted aspects of the draft Code in the Malaysian context cover accountability and its connection to reporting misuse (STRIDE and CBEP 2015, 38-39). Accountability requires scientists to raise their concerns with the relevant people, authorities and agencies when they are aware of any activities which are contrary to the BWC or other international treaties (STRIDE and CBEP 2015, 38). As for reporting misuse, the draft Code stresses that "[a]ny finding or suspicion of misuse of biological material, information or technology should be reported directly to competent persons or commissions" (STRIDE and CBEP 2015, 39). If future misuse of bioprinters occurs or if genetic material is synthesised and channelled for bioterrorism purposes, this should be reported to either the MDA, STRIDE or Royal Malaysian Police for appropriate action to be taken against those violating the Code. This would certainly be in line with the NTI-WEF report on good practice in monitoring gene synthesis needing a monitoring agency for reporting any unpredictable incident (NTI-WEF 2020, 11). Most importantly, the draft Code emphasises that individuals reporting the misuse are to be protected, which could mean their identity will be withheld and stipulates that they remain free from harassment (STRIDE and CBEP 2015, 39).

Furthermore, the supply, shipment and transport aspects highlighted in the draft Code emphasises the need to know the identity of the recipients of biological materials. This aspect of the Code could be broadened to cover the need for gene synthesis companies in Malaysia to screen their customers to ensure they are not persons of concern in relation to crime or identified terrorists seeking the services of gene synthesis to produce a pathogen of concern, as stipulated by the IGSC Harmonised Screening Protocol Version 2.0.

Additionally, internal and external communication related to Intangible Technology Transfer (ITT), encompassing emails, posts, telephone calls, and data concerning information about dual-use research and materials, have been emphasised to prevent access by unauthorised persons (STRIDE and CBEP 2015, 39). In the context of bioprinting, which uses software and the sending of a file through email to print a vaccine, the sender must ensure that the file is secured and not intercepted by a terrorist who will rewrite the file and change its code to produce a dangerous pathogen rather than a vaccine. The emphasis on cyberbiosecurity as mentioned earlier in the context of long distance communication involving bioprinting is very timely and relevant.

Lastly, the draft Code highlighting the aspect of research and knowledge-sharing involving the Dual Use Research of Concern (DURC) is a positive development (STRIDE and 
CBEP 2015, 39). Any DURC must be assessed when a researcher initially proposes research and during the execution of the research project. This is true for genetic material that may be used for bioprinting and for the bioprinter itself, which may be used for human wellbeing or for a malicious intent. In these scenarios, the researcher must then address how to overcome the potential risk as part of the risk management process.

Overall, Malaysia's draft Code is a document to be welcomed but is not without its flaws. There is an overemphasis on the physical biosecurity side with the assumption that terrorists would only target research facilities to acquire a biological agent. This is evident from the aim of the Code, which intends "to prevent microbial [resources] at research facilities from directly or indirectly contributing to the malicious misuses of biological agents and toxins" (STRIDE and CBEP 2015, 34). Development of synthetic biology and bioprinting and the potential for terroristic misuse shows that the drafters of this Code are not keeping abreast with biotechnological advancement. The case of Ahmed, the alleged ISIS terrorist with a $\mathrm{PhD}$ who said he could synthesise a biological weapon without obtaining its seed stock (highlighted earlier in this study), demonstrates that terrorists are up to date with biotechnological advancement.

Just in 2018, it was reported that security agencies within Southeast Asia discovered a plot by terrorists to develop anthrax and botulinum in Malaysia, and ricin and thorium in Indonesia (Ryacudu 2018, 1). This calls for the security agencies within Southeast Asia to improve intelligence gathering on terrorist movements, their activities and to share relevant information with their counterparts because terrorists can easily infiltrate Sabah given the porous borders with southern Philippines (Ryacudu 2018, 1). Any biological agents could then be smuggled into Sabah within Malaysian territory. Since terrorists in Southeast Asia already have the intention to create biological weapons, it is only a matter of time until they recruit an individual with an advanced degree and the expertise in synthetic biology and bioinformatics needed to develop biological weapons the modern way, rather than relying on traditional seedstock from laboratories or from Biological Resource Centres (BRCs).

If the drafters of the Code fail to introduce an initiative monitoring gene synthesis, as in the US guidance, IGSC Protocol, and in the NTI-WEF recommendation report, this could be a loophole in the final Malaysian Code of Conduct for Biosecurity, through which a crucial aspect of biotechnological development will have been neglected, creating a window of opportunity for terrorists within Malaysian borders to create mayhem.

Referring back to the Strategic Multilateral Biosecurity Dialogue that involved Singapore, Malaysia, Indonesia, and the US from 3-5 April 2017 in Washington, D.C., Malaysia's representative from STRIDE was asked if gene synthesis companies were present in Malaysia and whether they screen their orders and customers (Inglesby et al. 2017, 26). As the findings have shown, Malaysia currently lacks a specific regulation be it in binding or nonbinding form that would monitor gene synthesis companies, unlike the example of the US, which has a guideline for the said purpose. Malaysia's lack of regulation's to specifically monitor gene synthesis companies also seems to confirm the previous findings of Yassif, Santhakumar, and Lightfoot $(2015,4)$ that Asian countries have been slow to introduce regulations for the said purpose. This study proposed it is best that Malaysia, through STRIDE, create a separate and specific regulation or guideline of best practices for gene synthesis companies, following the US example, the IGSC Protocol and the NTI-WEF initiative on good practices for gene synthesis. In recapitulating, the US and South Korea in 2018 had previously proposed to work together to ensure that other countries be encouraged to have their own nationwide screening standards to monitor gene synthesis technology as previously highlighted by Woods et al.(2018, 30).

Furthermore, Gronvall $(2015,12)$ had emphasised that the US should ensure other countries with many gene synthesis companies, such as China, cultivate best practices like 
screening customers, screening gene synthesis orders and checking a customer's affiliation with a legitimate research organisation. Most importantly, Gronvall $(2015,12)$ indicated that China should similarly produce a guideline monitoring its gene synthesis companies through the cultivation of best practices, which this country lacks. By the same token, US government agencies providing technical assistance and training to stakeholders in Malaysia in charge of implementing the Biological Weapons Convention (BWC) should emphasise the need for a specific guideline of good practices among gene synthesis companies to ensure the monitoring of the genetic material they distribute so as not to perpetuate bioterrorism. This guideline could emulate the US example as discussed earlier, but changes could be made to suit local Malaysian circumstances. In the event that drafting a separate regulation or guideline may be time consuming, this study proposed that the existing draft Malaysian Code of Conduct for Biosecurity could add in an additional requirement to monitor the activities of gene synthesis companies, the genetic material they produce, screen the background of their customers and impose restrictions concerning who can own a bioprinter.

\section{CONCLUSION}

This study began with the objective of discovering whether Malaysia regulates and conducts DNA sequence screening among gene synthesis companies which are meant for bioprinting vaccines that could be misused for bioterrorism. This study found that Malaysia lacks a specific regulation be it in binding or non-binding form that would monitor gene synthesis companies and their activity of providing genetic sequencing services and pathogens to customers. In the event that Malaysian authorities are unable to produce a specific guideline that would regulate gene synthesis in the country, this study proposed that the existing draft Code of Conduct for Biosecurity be amended to include the need to monitor the activities of the gene synthesis companies, the genetic material they produce, screen the background of their customers and impose restrictions concerning who can own a bioprinter. The findings also indicated that the draft Code, due to its focus on the physical security of biological agents in the laboratory had neglected that synthetic biology and bioprinting may no longer require a biological agent to be created from a seedstock, given recent developments with chemical synthesis and DNA materials. The draft Code also neglects to address the digitalisation of biological agents embedded in digital files, as the biological lab of the future is envisioned to be more information-intelligent than requiring the high-level technical expertise of scientists. The implication is that cyberbiosecurity which refers to the security of digital files susceptible to interception and manipulation by terrorists for bioterrorism also needs to be emphasised to a far greater extent in the final Malaysian Code of Conduct for Biosecurity. As it is, the draft Code seems outdated in failing to consider the technological changes currently occurring in the field of synthetic biology, bioprinting and bioinformatics.

In conclusion, Malaysian policy makers amending the final Code of Conduct for Biosecurity should familiarise themselves with biotechnological changes currently occurring in the areas of synthetic biology and bioprinting as they need to keep at par with technological development as drafters of policy and law. Otherwise, Malaysia will be left behind as pertains to the regulation of gene synthesis leaving a void which could be exploited by terrorists and criminals with the intention to cause mayhem. As for the future direction of this study, it is proposed that a survey be done among gene synthesis companies in Malaysia regarding the number of companies aware of and practicing the IGSC Protocol. If there is a lack of awareness of the IGSC Protocol, it is imperative that STRIDE or another Malaysian authority introduce a document similar to the US guidance that would monitor gene synthesis companies and their 
activities to safeguard Malaysia's biosecurity from rogue terrorists who may plan a bioterrorism attack in the future.

\section{ACKNOWLEDGEMENTS}

The author wishes to thank the anonymous reviewers for their constructive comments.

\section{REFERENCES}

1540 Committee Group of Experts. 2013. Information note. 2013. https://www.un.org/en/sc/1540/documents/InformationNoteHongkongBioWorkshopMa r 2013-14.pdf (accessed on August 19, 2019).

Abbot, K.W. and D. Snidal. 2009. Strengthening international regulation through transnational new governance overcoming the orchestration deficit. Vanderbilt Journal of Transnational Law 42 (2): 501-78.

Academy of Sciences Malaysia. 2019. Promoting institutional oversight mechanisms to address biosecurity threats from emerging technologies. https://www.akademisains.gov.my/asm-focus/promoting-institutional-oversightmechanisms-to-address-biosecurity-threats-from-emerging-technologies/ (accessed on July 26, 2020).

Aiyappa, V. 2020. Using disease as a weapon is viewed with repugnance: UN chief. One India (Mumbai), March 30. https://www.oneindia.com/international/using-disease-as-aweapon-is-viewed-with-repugnance-un-chief-3061290.html (accessed on August 1, 2020).

Akpoviri, F., Z.A. Zainol, and S.N. Baharum. 2020. Synthetic biology and biosafety governance in the European Union and the United States. IIUM Law Journal 28 (1): 3771.

Bajema, N. A. 2018. "Weapons of mass destruction (WMD) in the digital age: Understanding the impact of emerging technologies". Research Paper No. 4. Emergence and Convergence Research Paper Series, Center for the Study of Weapons of Mass Destruction, National Defense University, Washington D.C., United States. https://wmdcenter.ndu.edu/Portals /97/UpdatedEnCno4.pdf?ver=2019-02-13-072413410 (accessed on August 19, 2019).

Bas, A. 2003. "Non-state actors in global governance: Three faces of power". No. 2003/4. Preprints Aus Der Max-Planck-Projektgruppe Recht Der Gemeinschaftsgüter. Bonn, Germany. $\quad$ https://www.econstor.eu/bitstream/10419/85112/1/2003-04_online.pdf (accessed on November 16, 2019).

Bradford, A. "Regime theory". In Max Planck encyclopedia of public international law. Oxford: Oxford University Press, 2007. http://scholarship.law.columbia.edu/cgi /viewcontent.cgi ?article $=2971 \&$ context=faculty_scholarship (accessed on November $16,2019)$.

Bügl, Hans et al. 2007. DNA synthesis and biological security. Nature Biotechnology 25 (6): 627-29.

Centers for Disease Control and Prevention, United States. 2018. Bioterrorism. https://www.cdc.gov/anthrax/bioterrorism/index.html (accessed on August 30, 2019).

Centers for Disease Control and Prevention, United States. 2019. Division of select agents and toxins: What is a select agent?. https://www.cdc.gov/cpr/dsat/what-is-select- 
agents.htm\#: :text=Division of Select Agents and,to animal or plant products (accessed on 27 September, 2020).

Colussi, I.A. 2015. Synthetic biology as a new threat to biosecurity. Is there a road to suitable governance? In Bioterrorism and biosecurity, ed. C.M.R. Casabona, 65-110. Bilbao: Cátedra Interuniversitaria de Derecho y Genoma Humano, Fundacion BBV Diputacion Foral de Bizkaia.

Committee on the Gene Drive Research in Non-Human Organisms: Recommendations for Responsible Conduct. 2016. Gene drives on the horizon: Advancing science, navigating uncertainty, and aligning research with public values. Washington D.C: The National Academies Press.

Cownie, F., and Bradney, A. (2013). Socio-legal studies: A challenge to the doctrinal approach. In Research methods in law, eds. Dawn Watkins, and Mandy Burton, 34-54. New York: Routledge.

Cutler, A. C., V. Haufler, and T. Porter. 1999. Private authority and international affairs. New York: SUNY Press.

Cutler, A.C. 2004. Private international regimes and interfirm cooperation. In The emergence of private authority in global governance, eds. Rodney Bruce Hall, and Thomas J. Biersteker, 23-40. Cambridge: Cambridge University Press.

Department of Health and Human Services (DHHS), United States. 2010. Response to public comments on draft screening framework guidance for synthetic double stranded DNA providers. $\quad$ https://www.phe.gov/s3/law/syndna/Documents/syndnacommentsresponse.pdf (accessed on August 20, 2019).

Diggans, J. and E. Leproust. 2019. Next steps for access to safe, secure DNA synthesis. Frontiers in Bioengineering and Biotechnology 7 (86): 1-6.

Dunlap, G. and E. Pauwels. 2017. "The intelligent and connected bio-labs of the future: Promise and peril in the fourth industrial revolution". Wilson Briefs, Science and Technology Innovation Programme, Wilson Center, Washington D.C., United States. https://www.wilsoncenter.org/sites/default/files/the_intelligent_connected_biolabs_of_t he_future.pdf (accessed on August 19, 2019).

Eberlein, B. and E. Grande. 2005. Beyond delegation: Transnational regulatory regimes and the EU regulatory state. Journal of European Public Policy 12 (1): 89-112.

Economic and Social Commission for Asia and the Pacific [ESCAP], The 2030 agenda for sustainable development and the future of technology, ESCAP/CICTSTI/2018/1 (June 21, 2018).

European Commission. 2019. Big data. https://ec.europa.eu/digital-single-market/en/bigdata\#: :text=Related topics\&text=Big data refers to large,records $\% 2 \mathrm{C}$ GPS signals\%2C etc (accessed on 27 September, 2020).

Firdaws, N. 2017. Bioterrorism threat: No worries for now. Free Malaysia Today (Petaling Jaya), January 31. https://www.freemalaysiatoday.com/category/nation/2017/01/31 /bioterrorism-threat-no-worries-for-now/ (accessed on August 1, 2020).

Foster, J. 2016. Do not hit print: The impact of 3D printing on distributive justice. Journal of Biosecurity, Biosafety and Biodefense Law 7 (1): 25-45.

Galamas, F. 2017. 3D printing: WMD proliferation and terrorism risks. Warsaw: Fundacja im. Kazimierza Pulaskiego.

Gallegos, J.A. and J. Peccoud. 2017. DNA is going digital- What could possibly go wrong? The Conversation (Brooklyn, New York), December 7. https://www.cbsnews.com/news/dna-goes-digital-cyberbiosecurity-risks/ (accessed on August 9, 2019). 
Garrett, L. 2013. The promise and perils of the synbio revolution. Foreign Affairs (New York), November/ December 2013. https://the-eye.unblock2.club/public/concen.org/Foreign Affairs.2013/Foreign Affairs.2013.6.pdf (accessed on August 19, 2019).

Gronvall, G.K. 2015. Mitigating the risks of synthetic biology. Discussion Paper, Council on Foreign Relations, New York, United States. https://backend-live.cfr.org /sites/default/files/pdf/2015/02/DiscussionPaper_Synthetic Biology.pdf (accessed on August 23, 2019).

Haufler, V. 1993. Crossing the boundary between public and private: International regimes and on-state actors. In Regime Theory and International Relations, ed. Volker Rittberger, 94111, Oxford: Clarendon Press.

Hernandez, D. 2012. Craig Venter imagines a world with printable life forms. Wired (New York), October 16. https://www.wired.com/2012/10/printable-life-forms/ (accessed on August 20, 2019).

Hyder, N. 2015. Developing facilitative governance frameworks for emerging biotechnologies: Exploring new approaches to cross-border regulation. $\mathrm{PhD}$ dissertation, University of Manchester, Manchester, United Kingdom.

Inglesby, T., A. Cicero, G.K. Gronvall, M.P. Shearer, and D. Meyer. 2017. Strategic multilateral biosecurity dialogue among Singapore, Malaysia, Indonesia, and the United States with participating observers from Thailand and Philippines. http://www.centerforhealthsecurity.org/our-work/pubs_archive/pubspdfs/2017/Meeting _Report_07.07.2017_FINAL.pdf (accessed on August 20, 2019).

International Gene Synthesis Consortium (IGSC). 2017. Harmonized screening protocol v 2.0: Gene sequence and customer screening to promote biosecurity. https://genesynthesisconsortium.org/wp-content/uploads/IGSCHarmonizedProtocol1121-17.pdf (accessed on November 20, 2019).

Kacarevic, Z.P. et al. 2018. An introduction to 3D bioprinting: Possibilities, challenges and future aspects. Materials 11 (11): 2199.

Koblentz, G., 2020. Emerging technologies and the future of CBRN terrorism. The Washington Quarterly 43(2): 177-196.

Maron, D.F. 2014. Weaponized ebola: Is it really a bioterror threat? Scientific American (Boston), September 25. https://www.scientificamerican.com/article /weaponized-ebolais-it-really-a-bioterror-threat/ (accessed on August 30, 2019).

Mary Ann Liebert Inc. 2014. A conversation with J. Craig Venter, PhD. Industrial Biotechnology 10 (1): 7-10.

Mishra, S. 2020. Daesh lockdown edition magazine appreciates Markaz for being COVID-19 superspreader. Times Now New.Com (Mumbai), June 4. https://www.timesnownews.com /india/article/daesh-lockdown-edition-magazineappreciates-markaz-for-being-covid-19-superspreader/601482. (accessed on July 26, 2020).

Moore, J. 2017. ISIS could use drones to spread deadly viruses, top terror chief warns. Newsweek (New York), November 27. https://www.newsweek.com /isis-could-usedrones-spread-deadly-viruses-top-terror-chief-warns-723012 (accessed on August 20, 2019).

Murch, R.S., W.K. So, W.G. Buchholz, S. Raman, and J. Peccoud. 2018. Cyberbiosecurity: An emerging new discipline to help safeguard the bioeconomy. Frontiers in Bioengineering and Biotechnology 6 (39): 1-6.

Nuclear Threat Initiative (NTI) and John Hopkins Bloomberg School of Public Health. 2019. Global Health Security (GHS) index: Building collective action and accountability. Washington D.C.: Nuclear Threat Initiative (NTI). 
Nuclear Threat Initiative and World Economic Forum (NTI-WEF). 2020. Biosecurity innovation and risk reduction: A global framework for accessible, safe and secure DNA synthesis.

http://www3.weforum.org/docs/WEF_Biosecurity_Innovation_Risk_Reduction.pdf (accessed on July 29, 2020).

Pashkov, V. and A. Harkusha. 2017. 3-D bioprinting law regulation perspectives. Wiadomosci Lekarskie 70 (3): 480-82.

Perello, E. 2018. CRISPR genome editing: A technical and policy primer. Editing Biosecurity, George Mason University, Wesport, Connecticut, United States. https://static1.squarespace.com/static/58eaf565197aea9c401e0497/t/5c05219c352f53c2 7698c60a/1543840164922/Perello_final_corrected.pdf (accessed on November 15, 2019).

Raimbault, B., J.P. Cointet, and P.B. Joly. 2016. Mapping the emergence of synthetic biology. Plos One 11 (9): 1-19.

Randerson, J. 2006a. Did anyone order smallpox? Guardian (London), June 23. https://www.theguardian.com/science/2006/jun/23/weaponstechnology.guardianweekly (accessed on August 20, 2019).

Randerson, J. 2006b. Revealed: The lax laws that could allow assembly of deadly virus DNA. Guardian (London), June $14 . \quad$ https://www.theguardian.com/world /2006/jun/14/terrorism.topstories3 (accessed on August 19, 2019).

Regalado, A. 2020. Biologists rush to re-create the China coronavirus from its DNA code. MIT Technology Review (Cambridge, Massachusetts), February 15. https://www.technology review.com/2020/02/15/844752/biologists-rush-to-re-create-the-china-coronavirusfrom-its-dna-code/ (accessed on August 1, 2020).

Ryacudu, R. 2018. Terrorism in Southeast Asia: The need for joint counter-terrorism frameworks. Counter Terrorist Trends and Analysis 10 (11): 1-3.

Schouten, G. and O. Hospes. 2018. Public and private governance in interaction: Changing interpretations of sovereignty in the field of sustainable palm oil. Sustainability 10 (4811): 1-15.

Science and Technology Research Institute for Defence (STRIDE), and Cooperative Biological Engagement Programme (CBEP). 2015. Workshop on the development of a National Code of Conduct for Biosecurity in the Framework of Biological and Toxin Weapons Convention. Kuala Lumpur: Academy of Sciences Malaysia.

Singapore Customs. 2019. List of dual-use goods. https://www.customs.gov.sg/businesses /strategic-goods-control/strategic-goods-control-list/list-of-dual-use-goods (accessed on 27 September, 2020).

Snow, J.A. 2015. Entering the matrix: The challenges of regulating radical levelling technologies. Master's Thesis, Naval Postgraduate School, Monterey, California, United States.

Speckhard, A. and A. Shajkovci. 2019. ISIS chemical-weapons expert speaks. Daily Beast (New York), March 11. https://www.thedailybeast.com/isis-chemical -weapons-expertspeaks-in-exclusive-interview (accessed on August 20, 2019).

Strategic Foresight Initiative. 2013. Envisioning 2030: US strategy for the coming technology revolution. Washington D.C. : Atlantic Council.

Thiel, M. and J. Maslanik. "Transnational actors". In Oxford Research Encyclopaedia, International Studies. Oxford: Oxford University Press, 2010. https://doi.org/10.1093/acrefore/9780190846626.013.105. (accessed on November 16, 2019).

Tran, J. L. 2015. To bioprint or not to bioprint. North Carolina Journal of Law and Technology 17 (1): $123-81$. 
Trump, B.D., S.E. Galaitsi, E. Appleton, D.A. Bleijs, M.V. Florin et al. 2020. Building biosecurity for synthetic biology. Molecular Systems Biology 16 (7): 1-6.

Tusikov, N. 2017. Transnational non-state regulatory regimes. In Regulatory Theory: Foundation and Applications, ed. Peter Drahos, 339-353. Canberra: Australia National University.

United States Department of Justice, and Federal Bureau of Investigation. 2011. Criminal and epidemiological investigation handbook. Washington D.C.: United States Department of Justice, and Federal Bureau of Investigation. https://www.cdc.gov/phlp/docs/ CrimEpiHandbook2011.pdf (accessed on 27 September, 2020).

Veiga, J.P.C. and M.A. Zacareli. 2017. International regimes: From public-intergovernmental to public-private transnational arena. Review of History and Political Science 5 (1): 4553.

Woods, B., V. Turekian, T. Jeong, G.K. Gronvall, E. Prescott, G. Lee, and R. Lewis. 2018. Building a smart partnership for the fourth industrial revolution. Washington D.C.: Atlantic Council.

Yassif, J., A. Santhakumar, and N. Lightfoot. 2013. Enhancing global security through infectious disease threat reduction. Global Health Security 2013/01, Chatham House, London, $\quad$ United https://www.chathamhouse.org/sites/default/files/public/Research/Global Kingdom. Health/0713pp_infectiousdiseasereduction1.pdf (accessed on August 19, 2019).

Zhou, D. et al. 2019. Biosafety and biosecurity. Journal of Biosafety and Biosecurity 1 (1): 1518.

\section{MARINA ABDUL MAJID}

Research Centre for History

Politics and International Affairs

Faculty of Social Sciences and Humanities

National University of Malaysia (UKM)

43600 Bangi, Selangor, MALAYSIA

*Corresponding author: marina76@ukm.edu.my / marinamajid76@gmail.com 